\title{
Pengungkapan Corporate Social Responsibility dan Nilai Perusahaan dengan Profitabilitas Sebagai Variabel Moderasi
}

\author{
Ni Nyoman Mira Miladeny ${ }^{1}$ \\ Fakultas Ekonomi dan Bisnis \\ Universitas Udayana, Indonesia
}

\author{
I Gst Ayu Eka Damayanthi² \\ Fakultas Ekonomi dan Bisnis \\ Universitas Udayana, Indonesia
}

Surel: miramiladeny@gmail.com

ABSTRAK

Penelitian ini bertujuan untuk memperoleh bukti empiris mengenai pengaruh Corporate Social Responsibility (CSR) dan mengetahui peran profitabilitas dalam memperkuat pengaruh Corporate Social Responsibility terhadap nilai perusahaan. Penelitian ini dilakukan pada perusahaan industri barang konsumsi yang terdaftar di Bursa Efek Indonesia periode 20172019. Jumlah sampel sebanyak 75 dalam 3 tahun amatan, dengan metode pengumpulan sampel menggunakan metode nonprobability sampling dengan teknik purposive sampling. Teknik analisis data menggunakan Moderate Regression Analaysis (MRA). Hasil penelitian menunjukkan CSR berpengaruh pada nilai perusahan dan profitabilitas tidak mampu memoderasi pengaruh CSR terhadap nilai perusahaan.

Kata Kunci: Corporate Social Responsibility (CSR); Nilai Perusahaan (Tobin'sQ); Profitabilitas (ROA).

\section{Disclosure of Corporate Social Responsibility and Company Value with Profitability as Moderating Variable}

\section{ABSTRACT}

This purpose to obtain empirical evidence regarding the effect of Corporate Social Responsibility (CSR) and to determine the role of profitability in strengthening the influence of Corporate Social Responsibility on firm value. This research was conducted on consumer goods industrial companies listed on the Indonesia Stock Exchange for the 2017-2019 period. The number of samples was 75 in 3 years of observation, with the method of collecting samples using the nonprobability sampling method with purposive sampling technique. The data analysis technique used Moderate Regression Analysis (MRA). The results of this research stated that CSR has an effect on firm value and profitability is not able to moderate the effect of CSR on firm value.

Keywords: $\quad$ Corporate Social Responsibility (CSR); Firm Value (Tobin's Q); Profitability (ROA).

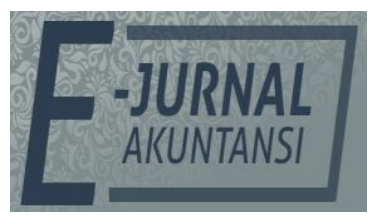

e-ISSN 2302-8556

Vol. 31 No. 12

Denpasar, Desember 2021

Hal. 3231-3243

DOI:

10.24843/EJA.2021.v31.i12.p15

PENGUTIPAN:

Miladeny, N. N. M. \&

Damayanthi, I. G. A. E.

(2021). Pengungkapan

Corporate Social Responsibility dan Nilai Perusahaan dengan Profitabilitas Sebagai Variabel Moderasi. E-Jurnal Akuntansi, 31(12), 3231-3243

RIWAYAT ARTIKEL:

Artikel Masuk: 14 Mei 2021

Artikel Diterima: 16 September 2021

Artikel dapat diakses: https:/ / ojs.unud.ac.id/index.php/Akuntansi/index 


\section{PENDAHULUAN}

Corporate Social Responsibility (CSR) merupakan suatu konsep yang sering dikaitkan dengan pembangunan ekonomi berkelanjutan karena konsep tanggung jawab sosial ini perlu mempertimbangkan dampak sosial yang timbul akibat operasi bisnis perusahaan terhadap masyarakat maupun lingkungan serta penanggulangan terhadap dampak-dampak tersebut apabila kemungkinan terjadi. World Business Council for Sustainable Development (WBCSD) menyatakan tanggung jawab sosial sebagai komitmen pembangunan ekonomi berkelanjutan, bekerjasama dengan karyawan dan perwakilan mereka, keluarga, komunitaslokal dan masyarakat pada umumnya untuk meningkatkan kualitas hidup dengan cara yang bermanfaat baik bagi bisnis maupun pembangunan (Harventy, 2020)

Undang-Undang Nomor 40 Tahun 2007 tentang Perseroan Terbatas pasal 1 ayat 3 menjelaskan mengenai tanggung jawab sosial dan lingkungan merupakan komitmen perseroan untuk berperan serta dalam pembangunan ekonomi berkelanjutan guna meningkatkan kualitas kehidupan dan lingkungan yang bermanfaat baik bagi perseroan sendiri, komunitas setempat, maupun masyarakat pada umumnya. Menurut ISO 26000 Corporate Social Responsibility merupakan tanggung jawab organisasi terhadap dampak-dampak yang ditimbulkan dari keputusan-keputusan serta kegiatan yang dilakukan pada masyarakat dan lingkungan yang diwujudkan melalui bentuk perilaku yang transparan dan etis yang sejalan dengan pembangunan berkelanjutan termasuk kesehatan dan kesejahteraan masyarakat, mempertimbangkan harapan pemangku kepentingan, serta sesuai dengan hukum yang ditetapkan dengan norma perilaku internasional serta terintegrasi dengan organisasi secara menyeluruh (Hamdallah et al., 2019).

Namun pada kenyataanya, masih ditemukannya kasus-kasus pengerusakan dan pencemaran lingkungan yang saat ini terjadi, seperti data yang ditunjukkan oleh Asosiasi Industri Olefin, Aromatik dan Plastik Indonesia (INAPLAS) serta Badan Pusat Statistik (BPS) menunjukkan data sampah plastik di Indonesia mencapai 64 juta ton per tahun dan sebanyak 3,2 juta ton diantaranya merupakan sampah plastik yang dibuang ke laut (Puspita, 2018), permasalahan sampah dan limbah telah menjadi permasalahan nasional bahkan internasional. Berdasarkan hasil penelitian yang dilakukan oleh (Jambeck et al., 2015) bahwa Indonesia menghasilkan sampah terbanyak nomor dua di dunia setelah China.

Pencemaran lingkungan di Indonesia khusunya sampah telah didominasi oleh sampah kemasan produk bermerek, hasil penelitian selama periode 20162019 yang dilakukan oleh organisasi Greenpeace menunjukkan hasil bahwa produk Indofood, Danone, Orang Tua, dan Wings sebagai produk dengan penyumbang sampah terbanyak, selain itu juga ditemukan berbagai jenis sampah non merek seperti sedotan, styrofoam, puntung rokok dan kantong plastik (Rezkisari, 2019). Kegiatan industri yang diluar kendali terkait lingkungan telah menciptakan krisis ekologi, serta menyebabkan beberapa fenomena seperti perubahan iklim, penipisan ozon, dan terjadi eksploitasi sumber dayaalam yang berlebihan, adanya polusi udara, pencemaran air yang mengakibatkan pengerusakan berkelanjutan terhadap marinir air, sehingga mengganggu pembangunan berkelanjutan dari lingkungan tersebut (Ado et al., 2020)

Perusahaan dalam menjalankan bisnisnya selain bertujuan memperoleh keuntungan juga berkewajiban untuk menjaga citra serta kelangsungan hidup 
perusahaan dengan memaksimalkan nilai perusahaan, karena nilai perusahaan juga merupakan tolak ukur dari tingkat keberhasilan suatu kinerja perusahaan yang tercermin dari harga saham di bursa saham. Praktik CSR merupakan bentuk tanggung jawab perusahaan dalam mengatasi masalah sosial dan lingkungan yang diakibatkan oleh aktivitas operasional perusahaan, dengan begitu CSR memiliki peran meningkatkan nilai perusahaan (Pramitha \& Sudana, 2021). Pelaksanaan CSR oleh perusahaan merupakan sinyal positif bagi para investor, sehingga menghasilkan keuntungan finansial bagi perusahaan (Fatmawati \& Asyik, 2019) yang berupa meningkatkannya harga saham tentu juga akan meningkatkan nilai perusahaan.

Berbagai penelitian yang dilakukan mengenai tanggung jawab sosial atau corporate social responsibility terhadap nilai perusahaan, menunjukkan hasil yang beragam. Hasil penelitian yang dilakukan (Daryanto et al., 2020), (Adiputra \& Hermawan, 2020), (Tanjung, 2020), (Nuswandari et al., 2018), (Yanto, 2018), (Armika \& Suryanawa, 2018), (Surya, 2018) menunjukkan hasil pengungkapan CSR berpengaruh positif dan signifikan terhadap nilai perusahaan, hasil penelitian ini menyatakan bahwa semakin banyak pengungkapan tanggungjawab sosial yang dilakukan oleh perusahaan berpengaruh terhadap peningkatan nilai perusahaan. Namun hasil penelitian berbanding terbalik dengan penelitian yang dilakukan oleh (Iswati, 2020), (Kalsum, 2020), (Suryati et al., 2019), (Hakim et al., 2019), (Lubis et al., 2018), (Pristianingrum, 2017) menunjukkan bahwa pengungkapan CSR tidak berpengaruh terhadap nilai perusahaan.

Inkonsistensi hasil penelitian diatas menjadikan motivasi dilakukannya penelitian dengan menggunakan pendekatan kontijensi. Pendekatan kontijensi digunakan untuk meneliti kemungkinan adanya variabel-variabel lain yang bertindak sebagai faktor moderasi atau mediasi yang mempengaruhi hubungan antara variabel independen dengan variabel dependen (Giri \& Dwirandra, 2014). Penelitian ini menggunakan variabel profitabilitas sebagai variabel kontijensi yang memoderasi hubungan pengungkapan Corporate Social Responsibility pada nilai perusahaan. Wulandari et al., 2016 menjelaskan bahwa semakin tinggi tingkat profitabilitas dalam perusahaan, maka semakin kuat pula hubungan antara pengungkapan tanggung jawab sosial pada nilai perusahaan.

Rasio profitabilitas merupakan salah satu rasio terpenting, rasio ini merupakan cerminan kemampuan perusahaan untuk menghasilkan laba selama satu periode, selain itu profitabilitas juga penting karena dapat menopang keberlangsungan dalam aktivitas perusahaan. Profitabilitas suatu perusahaan dijadikan sebagai penilaian efektivtas manajemen dalam mengelola modal investor. Perusahaan yang memiliki persentase profitabilitas tinggi akan berbanding lurus terhadap keuntungan yang akan diberikan kepada pemegang saham, kondisi ini juga akan meningkatkan nilai perusahaan yang dapat dilihat dari peningkatan harga saham, perusahaan diharapkan terus dalam kondisi menguntungkan dengan begituakan memberikan sinyal dan menjadikan investor tertarik berinvestasi dalam perusahaan yang bersangkutan (Suryani et al., 2019).

Penelitian ini dilakukan pada perusahaan manufaktur sektor industri barang konsumsi, hal yang melatar belakangi dipilihnya sektor industri barang konsumsi karena produknya yang terus dibutuhkan oleh masyarakat dalam kehidupan sehari-hari, dan menjangkau semua lapisan masyarakat. Selain itu 
dipilihnya sektor ini berdasarkan temuan oleh Yayasan Bali Fokus selama berpartisipasi dalam kegiatan brand audit atau audit merek, berdasarkan kegiatan tersebut didapati hasil bahwa pencemaran khususnya sampah plastik didominasi oleh produk Indofood, Unilever, Mayora, SiantarTop, dan Garuda Food (Suriyani, 2019) dimana produk-produk ini merupakan produk dari sektor industri barang konsumsi.

Penelitian ini dilandasi dengan dua teori yaitu teori sinyal dan teori stakeholder. Teori sinyal menurut (Spence, 1973) dalam penelitiannya yang berjudul Job Market Signalling menyatakan bahwa penyampaian informasi melibatkan dua orang atau lebih, penyampaian informasi ini dapat digambarkan oleh manajemen selaku pemberi kerja dengan calon karyawan, selain itu dapat digambarkan oleh manajemen (pihak internal) dengan investor (pihak eksternal) dimana dalam penyampaian informasi ini, pemilik informasi akan mencari cara untuk menyampaikan informasi sehingga akan terjadi transfer informasi yang dimilikinya dengan baik dan jelas, dengan tujuan akhir dapat memberikan informasi yang relevan untuk digunakan oleh pihak penerima. Sinyal atau informasi ini akan mempengaruhi keputusan- keputusan yang akan diambil oleh para pengguna laporan.

Teori sinyal menjelaskan bahwa perusahaan memberikan informasi karena adanya asimetri informasi, dengan begitu menjadikan dorongan perusahaan untuk melakukan publisitas (Tarmidi, 2019). Pengungkapan ini dilakukan perusahaan guna mengurangi asimetri informasi, perusahaan yang melakukan pengungkapan CSR akan memberikan informasi mengenai praktik CSR dan bagaiamana perusahaan mengatasi masalah-masalah yang timbul akibat aktivitas bisnisnya. Pengungkapan CSR yang sesuai dan tepat dengan harapan stakeholder akan memberikan sinyal berupa goodnews bahwa perusahaan memiliki prospek yang baik di masa depan dan akan meningkatkan nilai perusahaan (Darmastika \& Ratnadi, 2019).

Corporate Social Responsibility merupakan konsep tanggung jawab perusahaan yang juga berhubungan dengan teori stakeholder. Teori stakeholder menurut (Freeman, 1994) berbicara tentang individu maupun kelompok yang keberadaannya dipengaruhi ataupun mempengaruhi organisasi atau korporasi. Teori stakeholder juga menjelaskan bahwa suatu perusahaan tidak hanya beroperasi untuk kepentingan perusahaan itu sendiri, tetapi juga perlu memperhatikan dan memberi manfaat kepada stakeholder (Tenriwaru \& Nasaruddin, 2020).

Penelitian Darmawan \& Ikbal, 2019 menyatakan bahwa mayoritas konsumen akan meninggalkan sebuah produk apabila perusahaan dari produk tersebut memiliki citra yang buruk atau negatif. Perusahaan akan terus berupaya agar tetap dalam bingkai dan norma yang ada di dalam masyarakat atau lingkungan perusahaan tersebut beroperasi, dan memastikan aktivitas perusahaan sebagai suatu yang sah. Citra perusahaan yang baik akan membuat perusahaan dinilai lebih baik dan lebih menjanjikan untuk memberikan tingkat pengembalian yang stabil dengan demikian dapat menarik investor (Chumaidah \& Priyadi, 2018), dengan kata lain praktik CSR perusahaan membangun harmonisasi kepada segala aspek yang bersangkutan dengan aktivitas bisnis. Penelitian yang dilakukan oleh (Armika \& Suryanawa, 2018) menunjukkan hasil 
bahwa pengungkapan tanggung jawab sosial berpengaruh positif terhadap nilai perusahaan. Selain itu menurut Surya (2018) menunjukkan hasil bahwa adanya peningkatan corporate social responsibility akan meningkatkan nilai perusahaan. Berdasarkan uraian diatas, maka hipotesis dalam penelitian ini dapat dirumuskan sebagai berikut.

$\mathrm{H}_{1}$ : Pengungkapan Corporate Social Responsibility Berpengaruh Positif Pada Nilai Perusahaan.

Irwansyah et al., 2017 dalam penelitiannya menyatakan bahwa profitabilitas juga menjadi faktor manajemen melakukan pengungkapan tanggung jawab sosial secara bebas dan fleksibel, sehingga semakin tinggi tingkat profitabilitas suatu perusahaan maka semakin besar pula pengungkapan informasi sosial perusahaan. Penelitian (Fasya, 2018) dan (Darmastika \& Ratnadi, 2019) menunjukkan hasil bahwa profitabilitas mampu memoderasi (memperkuat) pengaruh pengungkapan CSR terhadap nilai perusahaan. Selain itu hasil penelitian yang dilakukan oleh (Murnita \& Putra, 2018) menunjukkan hasil bahwa semakin tinggi profit suatu perusahaan, maka semakin tinggi pula tingkat pengungkapan CSR yang dapat meningkatkan nilai perusahaan. Berdasarkan uraian diatas maka dirumuskan hipotesis sebagai berikut.

$\mathrm{H}_{2}$ : Profitabilitas Mampu Memperkuat Pengaruh Pengungkapan Corporate Social Responsibility Pada Nilai Perusahaan.

\section{METODE PENELITIAN}

Penelitian ini dilakukan pada perusahaan-perusahaan yang terdaftar di Bursa Efek Indonesia (BEI). Sumber datayang digunakan adalah datasekunder. Variabel independen dalam penelitian ini yaitu corporate social responsibility $(\mathrm{X})$, variabel moderasi dalam penelitian ini yaitu profitabilitas $(\mathrm{M})$ dan variabel dependen dalam penelitian ini yaitu nilai perusahaan $(Y)$. Penentuan sampel penelitian ini menggunakan metode purposive sampling dengan kriteria sebagai berikut: 1) perusahaan sektor industri barang konsumsi yang terdaftar dan tetap tercatat di BEI pada periode analisis yaitu 2017-2019, 2) perusahaan yang mempublikasikan laporan tahunan per 31 desember selama tiga tahun berturut-turut pada periode analisis yaitu tahun 2017-2019, 3) perusahaan yang memperoleh laba selama tiga tahun berturut-turut pada periode analisis 2017-2019, sehingga diperoleh 75 amatan dalam 3 tahun penelitian.

Nilai perusahaan dalam penelitian ini diproksikan dengan Tobin's Q. Rumus perhitungan Tobin's Q sebagai berikut.

$\mathrm{Q}=\frac{M V E+D E B T}{T A}$.

Pengukuran CSR diukur dengan Corporate Social Responsibility Disclosure Index (CSRDI) dengan tetap berpedoman pada indikator GRI, total indikator yang harus diungkapkan sebanyak 91 indikator (Julianto \& Megawati, 2020). Pengungkapan CSR dihitung menggunakan rumus sebagai berikut.

CSRDI $=\frac{\Sigma x i j}{\mathcal{N} j}$.

Profitabilitas dalam penelitian ini diproksikan dengan Return on Asset (ROA), ROA menggambarkan kemampuan perusahaan untuk menghasilkan laba dari aktiva yang dimiliki perusahaan (Fatmawati \& Asyik, 2019). Rumus perhitungan ROA sebagai berikut. 
$\mathrm{ROA}=\frac{\text { Laba bersih setelah pajak }}{\text { Total aset }}$

Teknik analisis data yang digunakan dalam penelitian ini adalah analisis statistik deskriptif, uji asumsi klasik, selanjutnya dilakukan analisis regresi dengan menggunakan analisis regresi linier sederhana untuk menguji hipotesis pertama dan moderated regression analysis(MRA) untuk menguji hipotesis kedua. Persamaan regresi yang dapat dirumuskan sebagai berikut.

$\mathrm{Y}=\alpha+\beta X+\varepsilon$

$\mathrm{Y}=\alpha+\beta_{1} X+\beta_{2} M+\beta_{3} X_{1} M+\varepsilon$

\section{HASIL DAN PEMBAHASAN}

Analisis statistik deskriptif dilakukan untuk memberikan gambaran tentang variabel-variabel dalam penelitian, analisis ini dilakukan sebelum melakukan pengujian asumsi klasik dan pengujian hipotesis. Statistik deskriptif menunjukkan jumlah sampel, rata-rata (mean), standar deviasi, varian, nilai maksimum, nilai minimum, sum, dan range (Ghozali, 2016: 19). Hasil dari statistik deskriptif dapat dilihat pada Tabel 1.

Tabel 1. Hasil Uji Statistik Deskriptif

\begin{tabular}{lccccc}
\hline Variabel & $\mathrm{N}$ & Minimum & Maximum & Mean & Std. Deviation \\
\hline TOBINSQ & 75 & 0,726 & 23,286 & 3,544 & 4,299 \\
$(\mathrm{Y})$ & 75 & 0,231 & 0,615 & 0,423 & 0,075 \\
CSR $(\mathrm{X})$ & 75 & 0,014 & 0,527 & 0,125 & 0,111 \\
ROA $(\mathrm{M})$ & 75 & & & \\
Valid $\mathrm{N}$ & 75 & & & & \\
(listwise) & & & & &
\end{tabular}

Sumber: Data Penelitian, 2021

Berdasarkan statistik deskriptif variabel nilai perusahaan yang diukur dengan Tobin's $Q$ berjumlah 75 sampel memiliki nilai minimum sebesar 0,726 pada perusahaan Budi Starch \& Sweetener Tbk (BUDI) tahun 2019 dan nilai maksimum sebesar 23,286 pada perusahaan Unilever Indonesia Tbk (UNVR) tahun 2017. Berdasarkan hasil statistik deskriptif dalam penelitian ini perusahaan Budi Starch \& Sweetener Tbk (BUDI) pada tahun 2019 memiliki nilai Tobin's Q < 1 maka perusahaan Budi Starch \& Sweetener Tbk (BUDI) dinyatakan undervalued, sedangkan Unilever Indonesia Tbk (UNVR) pada tahun 2017 dinyatakan overvalued karena nilai Tobin's $Q>1$. Variabel nilai perusahaan memiliki rata-rata sebesar 3,544 yang artinya bahwa perusahaan dalam penelitian telah berhasil dalam mengelola aktiva perusahaan atau overvalued, dan standar deviasi nilai perusahaan sebesar 4,299.

Corporate Social Responsibility yang diukur dengan CSRDI yang berjumlah 75 sampel memiliki minimum sebesar 0,231 pada perusahaan Tempo Scan Pacific Tbk (TSPC) tahun 2019 yang memiliki arti bahwa perusahaan tersebut melakukan pengungkapan CSR paling sedikit diantara perusahaan yang digunakan sebagai sampel penelitian, dan nilai maksimum sebesar 0,615 pada perusahaan Multi Bintang Indonesia Tbk (MLBI) tahun 2017, yang memiliki arti bahwa Multi Bintang Indonesia Tbk (MLBI) tahun 2017 melakukan pengungkapan CSR paling banyak diantara perusahaan dalam sampel penelitian . Variabel corporate social responsibility memiliki rata-rata sebesar 0,423 dan standar deviasi nilai perusahaan sebesar 0,075 
Profitabilitas yang diukur dengan ROA berjumlah 75 memproleh nilai minimum sebesar 0,014 pada perusahaan Chitose Internasional Tbk (CINT) tahun 2019 dan nilai maksimum sebesar 0,527 pada perusahaan Multi Bintang Indonesia Tbk (MLBI) tahun 2017. Variabel nilai perusahaan memiliki rata-rata sebesar 0,125 dan standar deviasi nilai perusahaan sebesar 0,111. Berdasarkan hasil statistik deskriptif dalam penelitian ini nilai maksimum diperoleh oleh per usahaan Multi Bintang Indonesia Tbk (MLBI) tahun 2017, hal ini memiliki arti bahwa perusahaan Multi Bintang Indonesia Tbk (MLBI) pada tahun 2017 dianggap mampu dalam mengelola penggunaan aset untuk menghasilkan laba bersih perusahaan, sedangkan perusahaan Chitose Internasional Tbk (CINT) pada tahun 2019 dianggap belum maksimal dalam mengelola penggunaan aset perusahaan karena memiliki nilai ROA terendah dalam penelitian ini.

Model regresi akan lebih tepat digunakan dan menghasilkan perhitungan prediksi yang lebih akurat apabila dapat memenuhi asumsi dalam uji asumsi klasik. Hasil uji normalitas pada penelitian ini memperoleh nilai signifikansi 0,069 $>0,05$. Hasil uji multikolinearitas nilai tolerance $0,867>0,10$ dan nilai VIF 1,153< 10. Hasil uji heteroskedastisitas memiliki nilai Sig. 0,088 dan 0,673 >0,05. Hasil uji autokorelasinya adalah du $(1,598)<\mathrm{dw}(2,175)<4$-du $(2,402)$. Berdasarkan uji asumsi klasik dalam penelitian ini seluruh data sudah memenuhi kriteria dalam uji asumsi klasik, sehingga layak dilakukan analisis lebih lanjut.

Tabel 2. Hasil Analisis Regresi Linier Sederhana

\begin{tabular}{lrrrrr}
\hline \multirow{2}{*}{ Model } & \multicolumn{2}{c}{ Unstandardized Coefficients } & $\begin{array}{c}\text { Standardized } \\
\text { Coefficients }\end{array}$ & \multirow{2}{*}{$\mathrm{t}$} & Sig. \\
\cline { 2 - 5 } & $\mathrm{B}$ & Std. Error & Beta & & \\
\hline 1 T (Constant) & $-8,636$ & 2,511 & & $-3,440$ & 0,001 \\
CSR $(\mathrm{X})$ & 28,795 & 5,847 & 0,499 & 4,925 & 0,000 \\
R Square & & & & & 0,249 \\
Adjusted $\mathrm{R}^{2}$ & & & & 0,239 \\
F hitung & & & & 24,253 \\
Sig. F & & & & 0,000 \\
\hline
\end{tabular}

Sumber: Data Penelitian, 2021

Berdasarkan pengujian statistik diperoleh nilai konstanta -8,636 memiliki arti apabila variabel CSR konstan atau tidak ada pengungkapan CSR (CSR=0), maka variabel nilai perusahaan bernilai sebesar $-8,636$. Koefisien regresi variabel CSR bernilai positif sebesar 28,795 memiliki arti apabila CSR meningkat sebesar satu satuan, maka nilai perusahaan juga akan meningkat sebesar 28,795 satuan. Pengujian statistik untuk hipotesis pertama tentang pengaruh corporate social responsibility terhadap nilai perusahaan diperoleh nilai signifikansi sebesar 0,000 dengan nilai $t$ hitung sebesar 4,925 dan koefisien regresi yang bernilai positif sebesar 28,795. Nilai signifikansi 0,000 < 0,05 mengindikasikan bahwa $\mathrm{H}_{0}$ ditolak dan $\mathrm{H}_{1}$ diterima.

Hasil uji F (F-test) pada Tabel 2, memiliki nilai signifikansi 0,000 < 0,05, ini menunjukkan model yang digunakan sebagai alat analisis dalam penelitian ini adalah model yang layak. Nilai Adjusted $R$ Square pada model persamaan pertama sebesar 0,239 atau sebesar 23,9\% artinya variasi nilai perusahaan dapat dijelaskan oleh variasi CSR $(X)$ sedangkan sisanya 76,1\% jelaskan oleh faktor lain yang tidak dimasukkan kedalam model. 
Hasil ini mempunyai arti bahwa corporate social responsibility berpengaruh positif dan signifikan pada nilai perusahaan. Sehingga disimpulkan bahwa luas pengungkapan CSR yang dilakukan oleh perushaan mempengaruhi peningkatan nilai perusahaan. Hasil penelitian ini mendukung teori sinyal dan teori stakeholder, teori sinyal menekankan bahwa perusahaan dalam upaya mengurangi asimetri informasi dan dalam upaya meningkatkan nilai perusahaan akan memberikan informasi yang dianggap dapat mengurangi asimetri informasi sekaligus untuk meningkatkan nilai perusahaan, dengan adanya pengungkapan CSR perusahaan telah penyampaian informasi terkait operasi bisnisnya sehingga perusahaan dianggap telah sah dan etis dalam menjalankan operasi bisnisnya. Hasil dari penelitian juga mendukung teori stakeholder karena terbukti bahwa perusahaan beroperasi tidak hanya untuk kepentingan perusahaan semata, tetapi tetap memberi manfaat kepada stakeholder sebagai bentuk tanggungjawab perusahaan atas dampak yang ditimbulkan dari aktivitas operasinya. Hasil penelitian ini sejalan dengan penelitian yang dilakukan oleh (Daryanto et al., 2020), (Adiputra \& Hermawan, 2020), (Tanjung, 2020), (Nuswandari et al., 2018), (Yanto, 2018), (Armika \& Suryanawa, 2018), (Wulandari et al., 2016) yang mengungkapkan bahwa pengungkapan CSR berpengaruh positif dan signifikan pada nilai perusahaan. Temuan ini bertentangan dengan penelitian yang dilakukan oleh (Iswati, 2020), (Kalsum, 2020), (Suryati et al., 2019), (Hakim et al., 2019), (Lubis et al., 2018), (Pristianingrum, 2017) mengungkapkan bahwa pengungkapan CSR tidak berpengaruh terhadap nilai perusahaan.

Tabel 3. Hasil Moderated Regression Analysis (MRA)

\begin{tabular}{|c|c|c|c|c|c|c|}
\hline & \multirow[t]{2}{*}{ Model } & \multicolumn{2}{|c|}{$\begin{array}{l}\text { Unstandardized } \\
\text { Coefficients }\end{array}$} & \multirow{2}{*}{$\begin{array}{c}\begin{array}{c}\text { Standardized } \\
\text { Coefficients }\end{array} \\
\text { Beta }\end{array}$} & \multirow[t]{2}{*}{$\mathrm{t}$} & \multirow[t]{2}{*}{ Sig. } \\
\hline & & B & Std. Error & & & \\
\hline \multirow[t]{8}{*}{1} & (Constant) & $-2,103$ & 2,180 & & $-0,965$ & 0,338 \\
\hline & $\operatorname{CSR}(X)$ & 4,872 & 5,077 & 0,084 & 0,960 & 0,340 \\
\hline & ROA (M) & 9,616 & 12,748 & 0,249 & 0,754 & 0,453 \\
\hline & CSR*ROA & 42,61 & 25,899 & 0,589 & 1,645 & 0,104 \\
\hline & $(\mathrm{XM})$ & 6 & & & & 0,772 \\
\hline & $\begin{array}{l}R \text { Square } \\
\text { Adjusted } \mathrm{R}^{2}\end{array}$ & & & & & 0,762 \\
\hline & F hitung & & & & & 79,938 \\
\hline & Sig. F & & & & & 0,000 \\
\hline
\end{tabular}

Sumber: Data Penelitian, 2021

Berdasarkan pengujian statistik diperoleh nilai konstanta -2,103 memiliki arti apabila variabel CSR konstan atau tidak ada pengungkapan CSR $($ CSR $=0)$, tidak ada perputaran laba terhadap aset $(R O A=0)$ dan tidak ada interaksi CSR dengan profitabilitas $\left(C S R^{*} \mathrm{ROA}=0\right)$, maka variabel nilai perusahaan bernilai sebesar -2,103. Koefisien regresi variabel CSR bernilai positif sebesar 4,872 memiliki arti apabila CSR meningkat sebesar satu satuan, maka nilai perusahaan juga akan meningkat sebesar 4,872 satuan. Koefisien regresi variabel ROA bernilai positif sebesar 9,616 memiliki arti apabila ROA meningkat sebesar satu satuan, maka nilai perusahaan akan meningkat sebesar 9,616. Koefisien regresi variabel interaksi antara CSR dan ROA bernilai positif sebesar 42,616 artinya a pabila terjadi penambahan satu satuan variabel interaksi, maka akan meningkatkan nilai perusahaan sebesar 42,616 satuan. 
Hasil uji F (F-test) pada Tabel 3, memiliki nilai signifikansi 0,000 <0,05, ini menunjukkan model yang digunakan sebagai alat analisis dalam penelitian ini adalah model yang layak. Tabel 4 menunjukkan nilai Adjusted $R$ Square pada model sebesar 0,762 atau $76,2 \%$ artinya bahwa variasi nilai perusahaan dapat dijelaskan oleh variasi CSR (X) dan variabel interaksi antara CSR dan ROA (XM) sebesar $76,2 \%$, sedangkan sisanya $23,8 \%$ dijelaskan oleh faktor lain yang tidak dimasukkan kedalam model.

Berdasarkan hasil MRA Tabel 3, menunjukkan nilai siginifikansi variabel moderasi yaitu interaksi antara corporate social responsibility (CSR) dengan return on asset sebesar 0,104 dengan t hitung sebesar 1,645 dan koefisien regresi bernilai positif sebesar 42,616. Nilai signifikansi 0,104 > 0,05 mengindikasikan bahwa $\mathrm{H}_{0}$ diterima dan $\mathrm{H}_{1}$ ditolak. Hasil ini mempunyai arti bahwa profitabilitas perusahaan yang diproksikan dengan ROA tidak mampu memperkuat pengaruh corporate social responsibility dalam meningkatkan nilai perusahaan. Berdasarkan statistik deskriptif bahwa rata-rata ROA 0,125 atau sebesar 12,5\% ini menunjukkan bahwa perusahaan memiliki kemampuan yang baik dalam menghasilkan laba, tetapi profitabilitas yang diproksikan oleh ROA tidak mampu memperkuat hubungan pengungkapan CSR pada nilai perusahaan. Hal ini dimungkinkan oleh beberapa faktor, perusahaan belum mampu menyisihkan anggaran untuk melakukan kegiatan tanggung jawab sosial, melainkan perusahaan lebih cenderung menyisihkan labanya untuk pembayaran dividen atau diakumulasikan untuk periode berikutnya (Armika \& Suryanawa, 2018).

Hasil penelitian ini tidak mendukung teori sinyal, dimana perspektif teori sinyal menjelaskan bahwa perusahaan dalam meningkatkan nilai perusahaan dapat memberikan sinyal berupa informasi kepada investor terkait kinerja perusahaan. Hal ini memberikan gambaran bahwa perusahaan industri barang konsumsi tergolong kedalam perusahaan ekonomis atau pelit, perusahaan ekonomis merupakan perusaahan yang memiliki profitabilitas tinggi tetapi memiliki anggaran CSR nya rendah (Wahyuni, 2018). Faktor lain disebabkan karena CSR merupakan strategi perusahaan dalam jangka panjang, berbeda dengan profitabilitas yang lebih banyak dilihat investor dalam jangka pendek. Penelitian ini juga tidak mendukung teori stakeholder, berdasarkan perspektif teori stakeholder bahwa perusahaan yang memiliki profitabilitas yang tinggi juga dapat meningkatkan harapan stakeholder bahwa perusahaan akan melakukan kewajiban terhadap pengungkapan kegiatan CSR, berdasarkan hasil penelitian bahwa perusahaan tidak mendukung teori stakeholder karena profitabilitas tinggi belum tentu perusahaan melakukan pengungkapan CSR yang lebih luas. Demikian hasil penelitian ini sejalan dengan (Dwinata, 2020), (Wulandari et al., 2020), dan (Armika \& Suryanawa, 2018) yang mengungkapkan bahwa profitabilitas tidak mampu memoderasi pengaruh pengungkapan CSR pada nilai perusahaan. Penelitian ini bertentangan dengan penelitian yang dilakukan oleh (Fasya, 2018), (Darmastika \& Ratnadi, 2019), (Murnita \& Putra, 2018) yang mengungkapkan bahwa profitabilitas mampu memoderasi (memperkuat) pengaruh pengungkapan CSR pada nilai perusahaan. 


\section{SIMPULAN}

Berdasarkan hasil analisis data yang dilakukan dapat disimpulkan bahwa corporate social responsibility berpengaruh pada nilai perusahaan. Selain itu, profitabilitas yang diproksikan dengan ROA tidak mampu memperkuat pengaruh CSR terhadap nilai perusahaan. Hasil analisis menunjukkan Corporate Social Responsibility (CSR) berpengaruh terhadap nilai perusahaan, hal ini memberikan gambaran bahwa pentingnya kegiatan CSR terhadap nilai perusahaan dan keberlanjutan perusahaan di masa depan, sedangkan variabel interaksi antaraCSR dengan profitabilitas tidak dapat memperkuat pengaruh hubungan pada nilai perusahaan, profitabilitas yang tinggi dalam perusahaan belum tentu pengungkapan CSR yang dilakukan juga lebih luas.

Bagi perusahaan disarankan untuk konsisten dalam melakukan pengungkapan CSR karena keberlangsungan perusahaan juga dipengaruhi oleh strategi perusahaan untuk jangka panjang salah satunya melalui aktivitas CSR. Selain itu manajemen perlu memastikan bahwa perusahaannya menyisihkan dana untuk kegiatan CSR agar tidak dipandang sebagai perusahaan yang ekonomis. Bagi penelitian selanjutnya dapat mengembangan penelitian untuk meneliti faktor lain yang berkaitan dengan nilai perusahaan seperti Good Corporate Governance (GCG), ukuran perusahaan, dan likuiditas, juga diharpakan dapat menggunakan atau menambah variabel bebas atau variabel moderasi lainnya. Penelitian ini hanya terbatas pada satu sumber saja yaitu laporan tahunan dan hanya berpedoman pada GRI, penelitian selanjutnya diharapkan dapat dapat menggunakan pedoman pengungkapan CSR dengan ISO 26000 atau dengan melakukan penelitian perbandingan pengungkapan CSR berdasarkan dua pedoman GRI dan ISO 26000. Penelitian selanjutnya diharapkan memperluas cakupan penilaian CSR dengan melihat dari sumber lainnya seperti website perusahaan, media sosial, maupun media cetak serta dapat memperpanjang periode pengamatan sehingga sampel yang digunakan lebih luas dan dapat menggambarkan kondisi nilai perusahaan.

\section{REFERENSI}

Adiputra, I. G., \& Hermawan, A. (2020). The effect of corporate social responsibility, firm size, dividend policy and liquidity on firm value: Evidence from manufacturing companies in Indonesia. International Journal of Innovation, Creativity and Change, 11(6), 325-338.

Ado, A., Abdulrasheed, A., Zubairu, A. A., \& Lamido, F. (2020). The Impact Of Profitability On Corporate Social Responsibility (CSR) Spending On Host Communities By Cement Manufacturing Companies. Global Journal of Applied, Management and Social (GOJAMSS), 19(5), 44-52.

Armika, A. A. A. M., \& Suryanawa, I. K. (2018). Pengaruh Pengungkapan Tanggung Jawab Sosial Pada Nilai Perusahaan dengan Profitabilitas Sebagai Variabel Pemoderasi. E-Jurnal Akuntansi Universitas Udayana, 22(1), 80-107. https:/ / doi.org/10.24843/EJA.2018.v22.i01.p04

Chumaidah, \& Priyadi, M. P. (2018). Pengaruh Profitabilitas dan Size Terhadap Nilai Perusahaan Dengan CSR Sebagai Variabel Pemoderasi. Jurnal Ilmu Dan Riset Akuntansi, 7(3), $1-20$. 
http:/ / jurnalmahasiswa.stiesia.ac.id/index.php/jira/article/ download/11 $6 / 113$

Darmastika, I. W. R., \& Ratnadi, N. M. D. (2019). Pengaruh Pengungkapan Corporate Social Responsibility pada Nilai Perusahaan Dengan Profitabilitas dan Leverage Sebagai Variabel Moderasi. E-Jurnal Akuntansi Universitas Udayana, 27(1), 362-387. https:/ /doi.org/10.24843/eja.2019.v27.i01.p14

Darmawan, \& Ikbal, M. (2019). Pengaruh Corporate Social Rensponblitiy (CSR) Terhadap Nilai Perusahaan Pada Bank BRI Cabang Parepare. Economos: Jurnal Ekonomi Dan Bisnis, 2(3), 112-119. https:/ / doi.org/10.31850/economos.v2i3.551

Daryanto, W. M., Janette, \& Angelina, L. (2020). Dose Corporate Social Responsibility Relate To Firm Value? International Journal of Business, Economics and Law, 21(3), 1-8.

Dwinata, A. (2020). The Effect of Corporate Social Responsibility (CSR) On Company Values with Company Profitability as Moderating Variables In Plantation Companies Listed In Indonesia Stock Exchange. International Journal Public Budgeting, Accounting and Finance, 3(1), 12-22.

Fasya, A. (2018). Pengaruh Pengungkapan Corporate Social Responsibility Terhadap Nilai perusahaan Dengan Profitabilitas Sebagai Variabel Moderasi. Jurnal Informasi Perpajakan, Akuntansi Dan Keuangan Publik, 13(2), 145-162. https:/ /doi.org/10.25105/jipak.v13i2.5012

Fatmawati, C. A., \& Asyik, N. F. (2019). Pengaruh Pengungkapan CorporateSocial Responsibility (CSR) Terhadap Nilai Perusahaan Dengan Profitabilitas Sebagai Variabel Moderasi. Jurnal Ilmu Dan Riset Akuntansi, 8(2), 1-17.

Freeman, R. E. (1994). The Politics of Stakeholder Theory : Some Future Directions. Philosophy Documentation Center, 4(4), 409-421. http:/ / www.jstor.org/stable/3857340 . Accessed:

Ghozali, I. (2016). Aplikasi Analisis Multivariatedengan Program IBM SPSS 25. Badan Penerbit Universitas Diponegoro: Semarang.

Giri, M. D. B. W., \& Dwirandra, A. A. N. B. (2014). Keadilan Distributif, Keadilan Prosedural, Dan Komitmen Tujuan Anggaran Sebagai Pemediasi Partisipasi Penganggaran Pada Kinerja Mnajerial. E-Jurnal Ekonomi Dan Bisnis Universitas Udayana, 208-226.

Hakim, L. N., Lestari, S., Widiastuti, E., \& Dewi, K. M. (2019). Pengaruh Pengungkapan Corporate Social Responsibility Dan Good Corporate Governance Terhadap Nilai Perusahaan Dengan Profitabilitas Sebagai Variabel Moderasi. Jurnal Pro Bisnis, 12(2), 25-32.

Hamdallah, A. A., Purwati, S., \& Boer, K. M. (2019). Implementasi Konsep "Hurier" Yang Dilakukan Oleh PT Pupuk Kalimantan Timur Kepada Masyarakat Ring 1. E-Journal Ilmu Komunikasi, 7(1), 293-305.

Harventy, G. (2020). Implementasi Program Tanggung Jawab Sosial Perusahaan Dalam Menciptakan Manfaat Bersama (Creating Share Value). Jurnal Akademi Akuntansi, 3(1), 36-43. https://doi.org/10.22219/jaa.v3i1.11161

Irwansyah, Lestari Ginting, Y., Kusumawardani, A., \& Erdiyanti, J. (2017). Corporate Social Responsibility Disclosure, Leverage, and Firm Value: The Moderating Role of Profitability. Atlantis Press. Advances in Economics, Business and Management Research (AEBMR): Mulawarman International 
Conference on Economics and Business (MICEB 2017), 35, 213-218. https:/ / doi.org/10.2991/miceb-17.2018.33

Iswati, W. (2020). The Impact of Disclosure Sustainability Reporting, Influence Corporate Social Responsibilities Towards Corporate Value with Mediation of Financial Performance. International Journal of Managerial Studies and Research (IJMSR), 8(1), 1-16. https:/ /doi.org/10.20431/2349-0349.0801001

Jambeck, J. R., Geyer, R., Wilcox, C., Siegler, T. R., Perryman, M., Andrady, A., Narayan, R., \& Law, K. L. (2015). Plastic waste inputs from land into the ocean. Science Journal, 347(6223), 768-770. https:/ / doi.org/10.1126/science.1260352

Julianto, B., \& Megawati, L. (2020). Pengaruh.CSR.dan.Kebijakan Dividen terhadap Nilai Perusahaan BUMN yang Terdaftar di BEI Periode 2013-2018. Jumal.Ekonomi,.Manajemen.Dan.Akuntansi, 3(2), http:/ / studentjournal.umpo.ac.id/index.php/isoquant

Kalsum, U. (2020). The Effect of Corporate Social Responsibility on Corporate Value; Case Study in LQ45 Company. Journal La Bisecoman, 1(1), 18-24. https:/ / doi.org/10.37899/journallabisecoman.v1i1.25

Lubis, N., Erlina, \& Bukit, R. (2018). The Effect Of Company Size, Capital Structure, Managerial Ownersip, Institutional Ownership And Disclosure Of Corporate Social Responsibilitu As A Moderating Variable In Property And Real Estate Companies Listed In Indonesia Stock Exchange. Journal of Public Budgeting, Accounting and Finance, 2(1).

Murnita, P. E. M., \& Putra, I. M. P. D. (2018). Pengaruh Corporate Social Responsibility Terhadap Nilai Perusahaan Dengan Profitabilitas Sebagai Variabel Moderasi. E-Jurnal Akuntansi Universitas Udayana, 23(2), 1470-1494. https:/ / doi.org/10.24843/eja.2019.v28.i01.p02

Nuswandari, C., Sunarto, S., Jannah, A., \& Ikromudin, I. (2018). Corporate Social Responsibility Moderated the Effect of Liquidity and Profitability on the Firm Value. Atlantis Press. Advances in Economics, Business and Management Research : 2nd International Conference on Banking, Accounting, Management and Economics (ICOBAME 2018), 86, 87-90. https:/ / doi.org/10.2991/icobame18.2019.19

Pramitha, I. A. Y., \& Sudana, I. P. (2021). Pengungkapan Corporate Social Responsibility, Kinerja Lingkungan dan Nilai Perusahaan. E-Jurnal Akuntansi Universitas Udayana, 31(3), 615-634. https:/ / doi.org/10.24843/EJA.2021.v31.i03.p08

Pristianingrum, N. (2017). Pengaruh Ukuran, Profitabilitas, dan Pengungkapan CSR Terhadap Nilai Perusahaan Manufaktur Yang Terdaftar di Bursa Efek Indonesia. Strategi Pengelolaan Sumber Daya Daerah Dalam Menciptakan Good Governance, 353-364.

Puspita, S. (2018). Indonesia Penyumbang Sampah Plastik Kedua Di Dunia. Kompas.Com.

https:/ / megapolitan.kompas.com/read/2018/08/19/21151811/indonesiapenyumbang-sampah-plastik-terbesar-kedua-di-dunia

Rezkisari, I. (2019). Sampah Kemasan Terbanyak dari Produk FMCG. Republika.Co.Ic. https:/ / republika.co.id/berita/nasional/ umum/19/11/12/q0ufu8328sampah-kemasan-terbanyak-dari-produk-fmcg 
Spence, M. (1973). Job Market Signaling. The Quarterly Journal OfEconomics, 87(3), 355-374. https:/ /doi.org/10.1055/s-2004-820924

Suriyani, L. De. (2019). Ini Merek Sampah Terbanyak Beberapa Sekolah di Bali. Mongabay.https://www.mongabay.co.id/2019/11/23/ini-merek-sampahterbanyak-beberapa-sekolah-di-bali/

Surya, L. P. (2018). Pengaruh Corporate Social Responsibility Terhadap Nilai Perusahaan Dengan Profitabilitas Sebagai Variabel Moderating. Jurnal Ilmu Dan Riset Akuntansi, 7(1), 1-18.

Suryani, A., Sari, Paramita, A., \& Atikah. (2019). Disclosure of Social Responsibility, Profitability to Improve the Company Value. KnE Social Sciences: International Conference on Economics, Management, and Accounting, 2019, 1008-1016. https://doi.org/10.18502/kss.v3i26.5427

Suryati, A. K., Gama, A. W. S., \& Astiti, N. P. Y. (2019). Pengaruh Corporate Social Responsibility Terhadap Nilai Perusahaan Dengan Profitabilitas Sebagai Variabel Moderasi (Studi Empiris Pada Perusahaan Pertambangan Yang Terdaftar di Bursa Efek Indonesia Periode 2014-2016). Forum Manajemen, 17(2), 111-121.

Tanjung, P. R. S. (2020). Effect of Corporate Social Responsibility Disclosure, Good Corporate Governance Implementation, and Profitability on Corporate Value (Asean Country Study 2016-2018). Saudi Journal of Business and Management Studies, 05(05), 274-283. https:/ / doi.org/10.36348/sjbms.2020.v05i05.001

Tarmidi, D. (2019). Tax Compliance and Uncompliance Entity: A Comparative Study of Investor Reaction. International Journal of Academic Research in Accounting, Finance and Management Sciences, 9(1), 105-110. https: / / doi.org/10.6007/ijarafms/v9-i1/5823

Tenriwaru, \& Nasaruddin, F. (2020). Pengaruh Pengungkapan Corporate Social Responsibility Terhadap Nilai Perusahaan Dengan Profitabilitas Sebagai Variabel Moderasi. Atma Jaya Accounting Research (AJAR), 3(01), 68-87.

Wahyuni, S. F. (2018). Pengaruh Corporate Social Responsibility Terhadap Nilai Perusahaan Dengan ProfitabilitasSebagai Variabel Moderating. Jurnal Ilmiah Magister Manajemen, 1(1), 109-117. https:/ / doi.org/10.30596/maneggio.v1i1.2371 homepage:

Wulandari, A. A., Ramantha, I. W., \& Wirakusuma, M. G. (2016). Dampak Moderasi Profitabilitas Terhadap Pengaruh Corporate Social Responsibility Pada Nilai Perusahaan Manufaktur. E-Jurnal Ekonomi Dan Bisnis Universitas Udayana, 5(7), 1889-1918.

Wulandari, Wibowo, S., \& Yunanto, A. (2020). Analisis Pengaruh Corporate Social Responsibility Dan Kebijakan Dividen Terhadap Nilai Perusahaan Dengan Profitabilitas Sebagai Variabel Pemoderasi Studi Pada Industri Perbankan. Jurnal Ekonomi, Bisnis, Dan Akuntansi (JEBA), 22(2), 144-157. https:/ / doi.org/10.32424/jeba.v22i2.1591

Yanto, E. (2018). Effect of Corporate Social Responsibility and Good Corporate Governance on the Value of Company with Profitability as Moderating Variables. Journal of Applied Accounting and Finance (JAAF), 2(1), 36-49. https:/ / doi.org/10.33021/jaaf.v2i1.304 